\title{
Hambatan Komunikasi Antarbudaya (Studi Kasus pada Mahasiswa Program Studi Magister Ilmu Komunikasi Universitas Gadjah Mada Angkatan 2019)
}

\author{
Shofwan Yusuf \\ Universitas Gadjah Mada \\ Yusufshofwan@gmail.com
}

\begin{abstract}
Abstrak
Hambatan komunikasi kerap muncul ketika terdapat perbedaan latar belakang budaya. Penelitian ini dilakukan untuk mengetahui hambatan komunikasi antarbudaya yang dialami oleh mahasiswa program studi Magister Ilmu Komunikasi UGM angkatan 2019 semester ganjil. Peneliti mendapati lebih dari 25 persen mahasiswa yang berasal dari luar pulau jawa, sehingga peneliti tertarik untuk mengetahui bagaimana hambatan komunikasi yang mereka alami baik dengan mahasiswa lainnya maupun dengan masyarakat Yogyakarta. Peneliti menggunakan metode studi kasus dengan pendekatan kualitatif. Studi kasus dipilih karena peneliti memiliki akses khusus, di mana peneliti memungkinkan untuk berinteraksi dengan informan. Teknik pengumpulan data dilakukan dengan cara wawancara dan observasi. Teknik analisis data menggunakan model communication barriers oleh Chaney \& Martin. Hasil penelitian menunjukkan bahwa informan mendapati beberapa hambatan dalam berkomunikasi baik di lingkungan perguruan tinggi, tempat tinggal sementara, dan beberapa tempat umum lainnya di Yogyakarta. Hambatan yang mereka temui adalah hambatan dari segi fisik, budaya, persepsi, motivasi, pengalaman, emosi, bahasa, non-verbal, dan kompetisi. Saran dari penelitian ini untuk penelitian kedepan adalah, perlunya memahami pola akulturasi mahasiswa yang berasal dari luar daerah ketika berada di perguruan tinggi.
\end{abstract}

Kata Kunci : Hambatan komunikasi, Komunikasi antarbudaya, Mahasiswa UGM

\begin{abstract}
Communication barriers often arise when there are differences in cultural backgrounds. This research was conducted to determine the barriers to intercultural communication experienced by students of the Masters of Communication Studies UGM class of 2019 odd semester. Researchers found that more than 25 percent of students came from outside Java, so researchers were interested in knowing how they experienced communication barriers both with other students and with the people of Yogyakarta. Researchers use the case study method with a qualitative approach. Case studies are chosen because researchers have special access, where researchers allow to interact with informants. Data collection techniques carried out by interview and observation. Data analysis techniques using the communication barriers model by Chaney \& Martin. The results showed that the informants found several obstacles in communicating both within the university environment, temporary housing, and several other public places in Yogyakarta. The obstacles they encounter are physical, cultural, perceptual, motivational, experiential, emotional, linguistic, non-verbal, and competition aspects. Suggestions from this study for future research are, the need to understand the pattern of acculturation of students who come from outside the area when they are in college.
\end{abstract}

Keywords: Communication barriers, Intercultural communication, UGM students 


\section{PENDAHULUAN}

Pembicaraan tentang komunikasi akan diawali dengan asumsi bahwa komunikasi berhubungan dengan kebutuhan manusia dan terpenuhinya kebutuhan berinteraksi dengan manusia-manusia lainnya ${ }^{1}$. Masyarakat Indonesia sedari dulu dikenal dengan heterogenitas dalam berbagai macam aspek, misalnya keberagaman suku bangsa, agama, bahasa, adat istiadat dan sebagainya ${ }^{2}$. Keberagaman suku dapat dikatakan sebagai banyaknya macam atau jenis suku, di mana dalam suatu wilayah tertentu terdapat beberapa suku yang memiliki budaya, bahasa, kepercayaan, tradisi dan adat dan memiliki identitas khusus ${ }^{3}$. Dialek Sunda dan Jawa relatif mirip jika dilihat dari intonasinya yang halus dan lemah lembut meskipun dalam kosa kata memiliki perbedaan dan pelafalan tersendiri ${ }^{4}$. Kondisi masyarakat Indonesia yang terdiri dari berbagai etnis dan suku inilah yang membuat Indonesia memiliki keunikan tersendiri untuk dilakukan eksplorasi lebih lanjut.

Di tengah kondisi masyarakat Indonesia yang memiliki berbagai budaya masingmasing, maka menjadi hal yang unik untuk mengamati lebih lanjut mengenai budaya komunikasinya. Budaya dikonseptualisasikan sebagai kerangka kerja yang mencakup aspek kognitif, afektif, dan perilaku yang memungkinkan seseorang untuk mengorientasikan diri mereka dalam hubungan satu sama lain dengan dunia dan untuk mengalami dan menafsirkan dunia dengan cara yang sama ${ }^{5}$. Keterkaitan antara komunikasi dan budaya memanglah menjadi hal yang perlu dibahas lebih dalam, baik mengamati pengaruhnya secara langsung maupun untuk tujuan deskriptif demi menjelaskan gambaran apa yang muncul dari relasi komunikasi dengan budaya.

Komunikasi antarbudaya adalah komunikasi yang terjadi di antara orang-orang yang memiliki kebudayaan yang berbeda misalnya berbeda ras, etnik, atau sosioekonomi, atau gabungan dari beberapa hal tersebut ${ }^{6}$. Universitas Gadjah Mada termasuk universitas tertua di Indonesia yang turut berperan sebagai pengemban Pancasila, berimplikasi pada motto Bhineka

\footnotetext{
1 Khoiruddin Muchtar, Iwan Koswara, and Agus Setiaman, 'Komunikasi Antar Budaya Dalam Perspektif $\begin{array}{llllll}\text { Antropologi', } & \text { Jurnal } & \text { Manajemen } & \text { Komunikasi, } & 1.1 & \text { (2019), }\end{array}$ <https://doi.org/10.24198/jmk.v1i1.10064>.

2 Suranto Aw, 'Implementasi Teori Komunikasi Sosial Budaya Dalam Pembangunan Integrasi Bangsa', Informasi, 45.1 (2015), 65 <https://doi.org/10.21831/informasi.v45i1.7771>.

${ }^{3}$ M. Khatimah, K., Saleh, R., \& Comn, 'Pola Komunikasi Antarbudaya Dalam Keberagaman Suku Di Daerah Perbatasan Provinsi Aceh (Studi Pada Suku Singkil Dengan Suku Pendatang Di Kecamatan Simpang Kiri Kota Subulussalam)', Jurnal Ilmiah Mahasiswa FISIP Unsyiah, 3.2 (2018), 279-92.

${ }^{4}$ Hedi Heryadi and Hana Silvana, 'Komunikasi Antarbudaya Dalam Masyarakat Multikultur', Jurnal Kajian Komunikasi, 1.1 (2013), 95-108 <https://doi.org/10.24198/jkk.vol1n1.9>.

${ }^{5}$ Gina G. Barker and Terri L. Cornwell, 'Acculturation, Communication, and Family Relationships: Challenges and Opportunities', Western Journal of Communication, $83.0 \quad$ (2019), 1-23 <https://doi.org/10.1080/10570314.2019.1620961>.

${ }^{6}$ Aw.
} 
Tunggal $\mathrm{Ika}^{7}$. Magister Ilmu Komunikasi UGM angkatan 2019 adalah program studi yang memiliki mahasiswa dengan asal daerah dan etnis yang beragam. Secara umum, masyarakat akan beranggapan bahwa mahasiswa yang belajar ilmu komunikasi tidak hanya mahir dalam berkomunikasi, tetapi juga mampu mengatasi masalah-masalah dalam komunikasi. Akan tetapi peneliti berasumsi bahwa tidak selamanya mahasiswa yang sedang belajar ilmu komunikasi mampu mengatasi kendala yang muncul dalam proses komunikasi antarbudaya.

Penelitian sebelumnya dilakukan oleh Sarga Surya $^{8}$ dengan hasil penelitian menunjukkan bahwa proses komunikasi yang terjadi pada masyarakat Sade telah mengalami perubahan, di antaranya adalah budaya patriarki yang mulai longgar di masyarakat Sade, mindset orangtua yang sudah berubah dan berpandangan jauh ke depan, simbol kekayaan seseorang tidak lagi dilihat dari banyaknya padi yang dimiliki tetapi fasilitas yang dimiliki seperti kendaraan bermotor dan peralatan rumah. Penelitian lain yang serupa dan terbaru dilakukan oleh Windaswara yang melihat dinamika komunikasi antarbudaya di dalam SMA Stella Duce $2^{9}$. Informan penelitian tersebut adalah siswi SMA Stella Duce 2 yang dipilih berdasarkan asal yaitu Papua dan Kalimantan. Hasil penelitian menunjukkan adanya dinamika komunikasi antarbudaya melalui bahasa, dan adanya konflik yang terjadi karena perbedaan budaya.

Dari beberapa penelitian terhadulu tersebut, terdapat perbedaan serta kebaruan dengan penelitian saat ini di mana penelitian saat ini memilih sampel yang lebih kompleks yang mencakup beberapa budaya di dalamnya. Perbedaan dan kebaruan lainnya adalah subjek penelitian saat ini adalah mahasiswa ilmu komunikasi, dengan asumsi peneliti bahwa mahasiswa ilmu komunikasi memiliki kemampuan komunikasi yang lebih baik dari mahasiswa di luar ilmu komunikasi, tetapi tidak selamanya mampu mengatasi kendala yang muncul dalam proses komunikasi antarbudaya. Peneliti juga memfokuskan kajian pada mahasiswa Magister Ilmu Komunikasi angkatan 2019 semester ganjil di mana terdapat setidaknya 14 orang mahasiswa berasal dari luar pulau jawa. Jumlah ini berkisar lebih dari $25 \%$ dari total mahasiswa di kelas tersebut. Dari kondisi tersebut maka peneliti tertarik untuk mengkaji hambatan komunikasi antarbudaya yang dialami oleh mahasiswa program studi magister ilmu komunikasi angkatan 2019 UGM dengan masyarakat di Yogyakarta.

\footnotetext{
7 'Universitas Gadjah Mada: Tentang UGM' < https://ugm.ac.id/id/tentang> [accessed 26 September 2019].

${ }^{8}$ Sarga Surya Data, 'Perubahan Pola Komunikasi Masyarakat Komunitas Suku Sasak Dusun Sade (Suatu Studi Etnografi Di Desa Wisata Komunitas Suku Sasak Dusun Sade Lombok Tengah)' (Universitas Gadjah Mada, 2014).

${ }^{9}$ Veronica Windaswara, 'Komunikasi Akulturasi Antarbudaya (Studi Kasus Pada Komunikasi Antarbudaya Di Dalam Akulturasi Siswi SMA Stella Duce 2 Yogyakarta)’ (Universitas Gadjah Mada, 2017).
} 


\section{LITERATUR REVIEW}

Hal-hal yang Termasuk dalam budaya kelompok sosial adalah segala sesuatu yang diproduksi dan dikembangkan oleh anggota kelompok itu-nilai-nilai, kepercayaan, artifak, dan bahasa mereka, seni mereka, hukum, agama, dan tentu saja, teori komunikasi, gaya, dan sikap ${ }^{10}$. Budaya mengacu pada totalitas pemikiran kelompok, pengalaman, dan pola perilaku dan konsepnya, nilai-nilai, dan asumsi tentang kehidupan yang memandu perilaku anggotanya ${ }^{11}$. Adapun proses pembagian informasi itu dilakukan baik secara lisan dan tulisan, bisa juga melalui bahasa tubuh, gaya, atau menggunakan bantuan benda lain di sekitar yang tujuannya untuk memperjelas pesan ${ }^{12}$. Singkat kata, komunikasi antarbudaya adalah komunikasi di antara orang-orang yang memiliki kepercayaan budaya, nilai-nilai, atau cara berperilaku yang berbeda ${ }^{13}$.

Dalam komunikasi multikultur, baik komunikasi antar individu maupun antar negara, seringkali pihak yang terlibat tidak bisa lepas dari latar belakang budaya yang sebelumnya ${ }^{14}$. Selain hal itu, dikenal pula istilah stereotip yang dapat menjadi gangguan komunikasi antarbudaya. Stereotip secara luas berarti konsep perihal sifat suatu golongan tertentu berdasarkan prasangka yang subjektif dan tidak tepat. Stereotyping adalah kecenderungan untuk mengembangkan dan mempertahankan kesan yang tetap, tidak berubah dari kelompok orang dan menggunakan kesan ini untuk mengevaluasi anggota individu dari kelompokkelompok ini, mengabaikan karakteristik individu yang unik ${ }^{15}$. Jadi stereotip menjadi sebuah hal yang mewujud berdasarkan prasangka dari pihak tertentu. Sukmono dan Junaedi menjelaskan bahwa proses stereotip dimulai ketika seseorang mulai mengidentifikasi seseorang lain sebagai anggota dari suatu kelompok tertentu, setelah itu memberikan penilaian kepada orang tersebut ${ }^{16}$.

Dalam konteks komunikasi multikultur, etnosentrisme juga muncul. Dalam konteks etnis, etnosentrisme merupakan paham atau keyakinan yang menganggap etnis sendiri lebih baik dibandingkan etnis lainnya ${ }^{17}$. Etnosentrisme adalah pola pikir sekaligus kepercayaan bahwa latar belakang budaya sendiri, (dalam hal ini termasuk cara menganalisis masalah, nilai,

\footnotetext{
10 Joseph A DeVito, Human Communication: The Basic Course, ed. by Essex Harlow, 2014th edn (Pearson, 2014).

${ }^{11}$ Fred E. Jandt, Conflict \& Communication (California: Thousand Oaks: SAGE Publications, 2017).

${ }^{12}$ Alo Liliweri, Dasar-Dasar Komunikasi Antar Budaya, cet. 3 (Yogyakarta: Pustaka Pelajar, 2007).

${ }^{13}$ DeVito.

14 Filosa Gita Sukmono and Fajar Junaedi, Komunikasi Multikultur: Melihat Multikulturalisme Dalam Genggaman Media (Yogyakarta: Buku Litera, 2014).

${ }^{15}$ DeVito.

${ }^{16}$ Sukmono and Junaedi.

${ }^{17}$ Sukmono and Junaedi.
} 
kepercayaan, dan komunikasi verbal maupun nonverbal) adalah benar, artinya yang lain adalah salah. Etnosentrisme percaya bahwa budaya mereka adalah budaya pusat serta budaya yang lain adalah tidak benar atau cacat ${ }^{18}$. Sehingga paham etnosentrisme yang mengkerdilkan budaya lain dapat memicu konflik ketika terjadi komunikasi antarbudaya. Terdapat beberapa teori yang mendukung mengenai komunikasi lintas budaya. Face negotiation theory adalah salah satunya, di mana terdapat empat asumsi teoretis sentral terkait face negotiation theory ${ }^{19}$. Kemudian dari sini muncul terminologi facework, yaitu perilaku yang dilakukan oleh pihak dalam komunikasi untuk melindungi wajah mereka sekaligus berusaha membentuk dan memperkuat wajah orang lain ${ }^{20}$.

Teori yang digunakan dalam penelitian ini adalah teori komunikasi antarbudaya dan komunikasi interpersonal oleh Chaney dan Martin (2014). Terdapat 9 jenis hambatan yang diantaranya adalah: (1) Fisik (Physical). Hambatan komunikasi semacam ini berasal dari hambatan waktu, lingkungan, kebutuhan diri, dan juga media fisik. (2). Budaya (Cultural). Hambatan ini berasal dari etnik yang berbeda, agama, dan juga perbedaan sosial yang ada antara budaya yang satu dengan yang lainnya. (3). Persepsi (Perceptual). Jenis hambatan ini muncul dikarenakan setiap orang memiliki persepsi yang berbeda-beda mengenai suatu hal. (4). Motivasi (Motivational). Hambatan semacam ini berkaitan dengan tingkat motivasi dari pendengar. (5). Pengalaman (Experiantial). Experiantial adalah jenis hambatan yang terjadi karena setiap individu tidak memiliki pengalaman hidup yang sama. (6). Emosi (Emotional). Hal ini berkaitan dengan emosi atau perasaan pribadi dari pendengar. (7). Bahasa (Linguistic). Hambatan komunikasi yang berikut ini terjadi apabila pengirim pesan dan penerima pesan menggunakan bahasa yang berbeda atau penggunaan kata-kata yang tidak dimengerti oleh penerima pesan. (8). Non-verbal. Hambatan non-verbal adalah hambatan komunikasi yang tidak berbentuk kata-kata tetapi dapat menjadi hambatan komunikasi. (9). Kompetisi (Competition). Hambatan semacam ini muncul apabila penerima pesan sedang melakukan kegiatan lain sambil mendengarkan ${ }^{21}$.

\footnotetext{
${ }^{18}$ Lillian H. Chaney and Jeanette S. Martin, Intercultural Business Communication, Internatio (New Jersey: Pearson, 2014).

19 James W. Neuliep and Morgan Johnson, 'A Cross-Cultural Comparison of Ecuadorian and United States Face, Facework, and Conflict Styles during Interpersonal Conflict: An Application of Face-Negotiation Theory', Journal of International and Intercultural Communication, 9.1 (2016), 1-19 <https://doi.org/10.1080/17513057.2016.1120844>.

${ }^{20}$ Sukmono and Junaedi.

${ }^{21}$ Chaney and Martin.
} 


\section{METODE}

Penelitian ini akan menggunakan metode studi kasus dengan pendekatan kualitatif untuk melihat hambatan komunikasi antarbudaya yang terjadi pada mahasiswa program studi magister ilmu komunikasi UGM angkatan 2019 semester ganjil. Melalui studi kasus, peneliti dapat melakukan penelitian lebih mendalam, dikarenakan peneliti memiliki kesempatan memperoleh wawasan mengenai konsep-konsep tingkah laku manusia ${ }^{22}$. Analisis kualitatif dipilih untuk melihat fenomena atau kenyataan sosial dalam suasana yang berlangsung secara natural atau alamiah, bukan dalam kondisi yang terkendali atau bersifat laboratoris ${ }^{23}$.

Pengumpulan data pada penelitian ini menggunakan teknik wawancara dan observasi. Observasi dilakukan peneliti dengan mengamati langsung interaksi dan komunikasi yang dilakukan informan. Dalam penelitian ini, peneliti memiliki akses khusus kepada infroman di mana posisi peneliti memungkinkan untuk sering berinteraksi dengan informan. Wawancara menjadi teknik pengumpulan data yang paling dominan dalam penelitian ini agar informasi dari informan dapat lebih banyak menjelaskan kepada peneliti.

Objek penelitian ini adalah hambatan komunikasi antarbudaya dengan subjek penelitian yaitu mahasiswa magister ilmu komunikasi UGM angkatan 2019 semester ganjil. Dalam pemilihan informan, peneliti menggunakan cara purposif atau menentukan informan dengan ciri dan kriteria tertentu. Kriteria informan yang dibuat oleh peneliti meliputi: (1) informan berasal dari mahasiswa Magister Ilmu Komunikasi UGM angkatan 2019 semester ganjil yang berasal dari beberapa pulau di antaranya meliputi: Jawa, Sumatera, Kalimantan, Sulawesi, Kepulauan Nusa Tenggara (termasuk Bali); (2) informan merupakan mahasiswa yang sebelumnya belum pernah tinggal di Yogyakarta.

Informan dari Pulau Jawa diambil dari mahasiswa Jawa Barat, yang dekat dengan etnis Sunda (inisial N). Dalam mengambil informan dari Pulau Kalimantan, diambil dari mahasiswa yang berasal dari Banjarmasin (Inisial A) sementara informan dari Pulau Sulawesi, diambil dari mahasiswa yang berasal dari Gorontalo (Inisial AF), dan pengambilan informan dari Pulau Sumatera, diambil dari mahasiswa yang berasal dari kota Palembang dan Jambi (inisial R dan F). Mengingat tidak ada informan dari Pulau Papua, maka diambil dari mahasiswa yang berasal dari Kepulauan Nusa Tenggara (Inisial S). Setiap informan akan diberikan inisial masingmasing untuk membedakan dengan informan lainnya, serta untuk menyamarkan identitas asli

${ }^{22}$ Robert K. Yin, Studi Kasus : Desain Dan Metode, 1st edn (Jakarta: Rajagrafindo Persada, 2008).

23 Rostini Anwar and Hafied Cangara, 'Rintangan Komunikasi Antar Budaya Dalam The Intercultural Communication Barriers of Marriage and Divorce Between Java and Papua Ethnics in The City of Jayapura (Conflict Management Strategy in Husband and Wife Interpersonal Relationship)', Jurnal Komunikasi KAREBA, 5.2 (2016), 273-85 <https://doi.org/10.31947/kjik.v5I2.1906>. 
informan. Hal tersebut juga dikarenakan terdapat hal-hal yang bersifat sensitif dan bersinggungan dengan sesama teman lainnya.

\section{Hasil}

Pengamatan dan wawancara dilakukan peneliti mulai tanggal 12 Agustus - 12 November 2019 terhadap informan yang sudah dipilih. Masalah komunikasi antarbudaya yang dialami meliputi aspek fisik, budaya, persepsi, motivasi, pengalaman, emosi, bahasa, nonverbal dan kompetisi.

1. Fisik: Hambatan fisik ini dialami oleh informan R kaitannya dalam hal makanan. Hal ini sesuai dengan pernyataan informan $\mathrm{R}$ sebagai berikut:

"makanan, Mas. Rasanya aneh begitu, kok bisa ya makan hanya dengan satu lauk saja. Saya di rumah biasanya itu lauknya macam-macam. Ikan, ayam, tempe, sayur, macammacamlah. Pernah itu, ambil nasi angkringan satu, tapi lauknya ambil macam-macam. Telur puyuh, tempe, tahu, ampla, ceker, kerupuk, macam-macam lah. Nah itu dilihatin kan sama orang, saya pikir, apa ya yang salah. Kok sampe diliatin orang. Ternyata orang sini sukanya makan pake lauk 1 aja ya." (R, 2019)

Dari hasil wawancara tersebut dapat dijelaskan bahwa informan R merasa seperti beda sendiri ketika sedang makan bersama teman-teman di Yogyakarta.

2. Budaya: Hambatan budaya muncul disampaikan oleh informan F. Pengalaman F ketika berjalan sepanjang gang beberapa kali disapa oleh masyarakat sekitar, baik yang duduk atau simpangan jalan. Cara masyarakat menyapa $\mathrm{F}$ adalah dengan cara menunduk dan tersenyum. Tanpa ada bahasa dan kalimat yang muncul. Hal ini awalnya menimbulkan pertanyaan oleh $\mathrm{F}$ mengenai bagaimana cara bersikap yang tepat sementara dalam kehidupan sehari-hari $\mathrm{F}$ yang dulu, dari daerah asalnya, tidak terbiasa melakukan itu.

"ya akhirnya sekarang malah saya ikut-ikutan nunduk dan senyum, Mas, ke orang-orang di sekitar yang ngga dikenal. Soalnya aneh aja gitu kalo ngga nunduk ketemu orang, padahal dulunya mah engga" - (F, 2019)

Hambatan budaya lain yang dialami oleh $\mathrm{F}$ adalah ketika berkendara sepeda motor dan penggunaan klakson.

"yang unik tuh ya, harusnya kalo lampu udah ijo, kan jalan kan ya. Itu malah orang-orang di belakang pada diem aja, ngga ada klakson ngga apa. Kayak sabaaaaar gitu, selooow gitu, beda banget lah sama yang di sana. Aneh lagi malah pas klaksonin orang di jalan, Mas. Bukannya orangnya minggir, eh ini malah nengok ke belakang. Dikira saya ini temennya gitu kali ya, kayak ngerasa disapa gitu kali ya kalo diklaksonin” (F, 2019) 
kasus serupa yang dialami oleh $\mathrm{F}$ juga dialami oleh informan R. R merasa bahwa masyarakat Yogyakarta jauh lebih tertib ketika sedang di simpang traffic lights.

"di sini mas, kalo lampu merah tengah malam itu, orang naik motor tetep berhenti. Padahal ngga ada siapa-siapa, sepi, cuman ada jin kali ya. Nah kalo begitu, akhirnya saya kan terpaksa ikut berhenti. Kalau di sana (daerah saya), sudah malam ya ngga usah berhenti lagi kalo lampu merah, udah sepi banget soalnya. Tapi di sini, meskipun sepi tetep aja berhenti. Beda ya ternyata." (R, 2019)

Dari hasil wawancara tersebut dapat dijelaskan bahwa informan $\mathrm{F}$ dan $\mathrm{R}$ merasa memiliki perbedaan kebiasaan dalam melakukan sesuatu. Secara tidak langsung, hal itu menggambarkan perbedaan perilaku berbudaya yang mengharuskan terhambatnya komunikasi yang efektif.

3. Persepsi: Hambatan persepsi diakui oleh beberapa informan dalam tataran petunjuk arah. Informan $\mathrm{F}, \mathrm{AF}, \mathrm{N}$, dan $\mathrm{S}$. keempat informan tersebut mengungkapkan permasalahan persepsi mengenai petunjuk arah.

"harusnya kan kalo ditanya, Pak gedung ini di sebelah mana ya, itu jawabnya lurus ke sana mas, terus belok kiri, atau belok kanan, begitu. Eh malah jawabnya kadang-kadang, ini ke utara terus aja mas, nanti gedungnya di timurnya gedung A, begitu. Kan malah bingung, niatnya nanya biar ngga sesat di jalan, malah akhirnya nanya orang makin bingung" - $(\mathrm{N}$, 2019)

Menanggapi persepsi arah di atas, kini informan $\mathrm{N}$ sudah memiliki tips untuk mengatasi hal itu. Yakni dengan mengamati bagaimana cara yang mudah memahami arah di Yogyakarta ini. Caranya adalah berpatokan pada Gunung Merapi. Menurut N, posisi Gunung Merapi akan selalu di utara. Artinya jika sesekali tampak Gunung Merapi, maka itulah utara. Berarti, sebelah kanan adalah timur, sebelah kiri adalah barat, serta belakang diri kita adalah selatan.

4. Motivasi: Hambatan motivasi dialami oleh $\mathrm{F}$ ketika sedang menanyakan alamat kepada seseorang. Suatu ketika, F sedang mengendarai sepeda motor di sebuah gang. Kemudian karena ingin mengetahui alamat sebuah tempat tertentu, F bertanya kepada seorang bapak-bapak di pinggir jalan. Namun menurut F, bapak-bapak tersebut tampak tidak peduli dengan pertanyaan F. F menyampaikan bahwa sudah bertanya dengan sopan, namun respon dari bapak-bapak tersebut menurut F membuat tidak nyaman.

"aku udah bilang permisi, loh, Mas. Udah bilang juga mau nanya alamat ini, di mana, lewat mana. Terus bapaknya cuman bilang, ke sana, udah gitu doang. Terus kaya ngga peduli" (F, 2019)

Dari wawancara lebih lanjut dengan $\mathrm{F}$, peneliti meminta $\mathrm{F}$ untuk mengulang kronologi kejadiannya. Kemudian dari sana peneliti mengetahui bahwa F ketika bertanya kepada bapakbapak di pinggir jalan adalah tetap di atas motor, tidak mematikan mesin motor, dan tidak 
melepas helm. Barangkali hal itulah yang menyebabkan bapak-bapak sebagai lawan komunikasi F sebagaimana yang diceritakan F.

5. Pengalaman: Hambatan pengalaman dialami oleh $\mathrm{S}$ ketika beberapa kali naik ojek online. $\mathrm{S}$ merasa terganggu ketika ditanya daerah asal yang kemudian lanjut kepada komentar setelah menyebutkan daerah asalnya.

" aku ngga tau ya, Mas. Mungkin nanya daerah di sini udah biasa, sebagai ramah tamah atau apa lah. Tapi itu ngga enak bagi saya. Makanya aku suka menghindar kalo udah nanya-nanya daerah asal.” (S, 2019)

Dari wawancara tersebut dapat dilihat bahwa dari perbedaan pengalaman seseorang, dapat berujung pada stereotip yang negatif. Maka dari itu, komunikasi dapat terhambat apabila pengalaman salah satu pihak jauh berbeda dengan pihak lainnya karena akan mengarah kepada perbedaan pandangan akan suatu hal.

6. Emosi: Hambatan emosi dialami oleh F ketika sedang dalam diskusi bersama mahasiswa lokal, bukan sesama mahasiswa dari Sumatera.

"orang sini kalo ngomong Jancuk Jancuk gitu tuh kayak mau pukul orang ya mas? Jadi takut aku tuh" (F, 2019)

Dari wawancara di atas, dapat dilihat bahwa munculnya emosi seseorang akan berpengaruh pada komunikasi. Seseorang bisa untuk tidak melanjutkan komunikasi dikarenakan lawan bicara tampak emosional. Hal ini menyebabkan efektifitas komunikasi dapat terganggu.

7. Bahasa: Hambatan bahasa dialami oleh A ketika sedang transaksi di pasar tradisional.

"itu Mas, waktu belanja di pasar itu, kan udah bisa kan dikit-dikit pake bahasa jawa misalnya pinten Bu? Nggih, mboten, gitu-gitu udah paham. Tapi, kalo si ibuknya udah bilang Selangkung Mbak, Gangsal-Welas, udah pusing aku, ngga ngerti. Yaa cara paling mudahnya sih emang nanya lagi, berapa-berapanya. Tapi cara lain yang lebih mudah, ya kasih aja uang seratus ribu, pasti kan ada kembalian tuh. Nah berarti tinggal inget-inget aja. Hehee" (A, 2019)

Dari wawancara di atas dapat dilihat bahwa perbedaan bahasa, dapat menjadi hambatan komunikasi. Informan perlu meminta lawan bicara untuk mengulang kalimat dengan bahasa Indonesia agar dapat diketahui maksudnya. Hal ini dikarenakan lawan bicara informan menggunakan bahasa Jawa, bahasa yang tidak terlalu dipahami oleh informan.

8. Non-verbal: Hambatan non verbal dialami oleh $\mathrm{S}$ ketika sedang berkomunikasi dengan masyarakat lokal di sekitar kampus. S menyadari kalau di Jawa, orang lebih cenderung 
menggunakan jempol untuk menunjuk sesuatu. Sementara $\mathrm{S}$ tidak terbiasa menunjuk sesuatu menggunakan jempol, dan S cenderung menggunakan "palingan muka" untuk menunjuk arah.

"Bahkan ya mas, di daerahku, kalo orang jualan ayam hidup di pasar, itu penjualnya kadang nunjuknya pake kaki loh. Dan itu ngga apa-apa” (S, 2019)

Dari wawancara tersebut, dapat dilihat bahwa perbedaan bahasa non-verbal menjadi hambatan komunikasi antar budaya.

9. Kompetisi: Hambatan kompetisi tidak secara ekspilisit ditemui oleh peneliti, informan pun tidak banyak menyinggung hambatan-hambatan komunikasi yang dapat dikategorikan dalam hal hambatan kompetisi sesuai dengan konsep Chaney dan Martin. Namun hasil observasi peneliti menunjukkan bahwa terdapat hambatan kompetisi pada proses komunikasi sebagian informan. Pada informan S, peneliti melihat bahwa $\mathrm{S}$ adalah sosok yang tidak terlalu antusias ketika proses komunikasi. Namun informan AF adalah sosok yang antusias ketika proses komunikasi. Artinya AF dan S seperti memiliki sifat yang berkebalikan. Peneliti melihat ketika terjadi komunikasi antara AF dan S secara tidak sengaja, tampak bahwa AF merasa tidak diperhatikan ketika S yang diajak bicara malah memainkan handphone nya dan sibuk sendiri. Dari kejadian itu, peneliti menyimpulkan bahwa hambatan komunikasi dialami oleh AF ketika sedang berkomunikasi dengan $\mathrm{S}$.

\section{PEMBAHASAN}

Hambatan dalam komunikasi muncul disebabkan oleh adanya perbedaan budaya. Maka hal inilah yang dimaksud dengan hambatan komunikasi antar budaya. Dalam hal ini fokus kajian diterapkan pada mahasiswa yang berasal dari luar kota Yogyakarta. Adanya peluang munculnya hambatan komunikasi antarbudaya ini dikarenakan mahasiswa perantauan harus tinggal untuk waktu yang cukup lama. Bagi mereka mahasiswa perantauan, masyarakat Yogyakarta mempunyai kebiasaan budaya yang berbeda dengan budaya tempat kelahirannya, sehingga mereka mendapati perbedaan dalam berbagai hal seperti cara makan, sikap sopan ketika bertemu dengan seseorang, atau cara menegur orang lain saat bertemu di jalan.

Perbedaan cara atau sikap dalam berinteraksi dan melakukan komunikasi tersebut yang menyebabkan munculnya hambatan dalam berkomunikasi. Contoh kasus hambatan komunikasi antarbudaya yang dipaparkan dalam hasil penelitian di atas menunjukkan adanya hambatan komunikasi antarbudaya dalam berbagai aspek. Hal ini seperti apa yang dikemukakan oleh Chaney dan Martin bahwa ada 9 jenis hambatan dalam komunikasi. Berdasarkan hasil wawancara didapati bahwa semua informan merasa ada perbedaan yang 
mencolok di beberapa kebiasaan maupun budaya yang dilakukan masyarakat di Yogyakarta dengan kebiasaan masyarakat di tempat tinggal asalnya sehingga menimbulkan hambatan komunikasi bagi mereka.

Beberapa informan terlihat ingin menyamai sikap dan kebudayaan masyarakat setempat seperti halnya mengikuti cara menyapa orang lain ketika berpapasan dengan cara tersenyum atau menundukkan kepala dan mulai membiasakan diri dengan tidak mengambil lauk lebih dari satu ketika makan bersama teman-temannya. Hal ini menunjukkan adanya proses integrasi budaya yang dilakukan oleh informan sebagai mahasiswa perantauan. Dalam hal ini informan melakukan upaya menjadi bagian integral dari masyarakat Yogyakarta dengan cara menghormati budaya mereka ketika berada di tengah-tengah masyarakat, tetapi mereka tidak lantas melupakan atau mengganti budaya asli mereka dengan budaya baru yang mereka temui di Yogyakarta.

\section{KESIMPULAN}

Berdasarkan hasil penelitian dan pembahasan yang dipaparkan di atas dapat disimpulkan bahwa mahasiswa Program studi Magister Ilmu Komunikasi UGM angkatan 2019 semester ganjil yang berasal dari luar kota Yogyakarta menemui beberapa hambatan dalam komunikasi. Hambatan komunikasi yang terjadi tidak hanya ketika berinteraksi dengan sesama teman kuliahnya tetapi juga dengan masyarakat Yogyakarta di sekitar tempat tinggalnya. Munculnya hambatan dalam komunikasi antarbudaya ini terjadi karena adanya perbedaan budaya baik sikap maupun perilaku yang menurut mereka berbeda dengan budaya yang biasa mereka lakukan di tempat tinggal asalnya.

Hambatan yang mereka alami tersebut meliputi hambatan dari jenis fisik, budaya, bahasa, emosi, pengalaman, motivasi, bahasa, non-verbal dan kompetisi. Di samping itu, informan menunjukkan adanya upaya melakukan adaptasi budaya dengan cara menyamai sikap dan perilaku masyarakat di Yogyakarta ketika melakukan aktivitas bersama. Dengan demikian, dapat dikatakan bahwa meskipun informan merupakan mahasiswa dari program studi Ilmu Komunikasi, bukan berarti mereka tidak menemui hambatan dalam berkomunikasi akan tetapi setidaknya mereka mempunyai upaya integrasi untuk mengurangi hambatan dalam berkomunikasi antarbudaya.

Saran dari penelitian ini untuk penelitian kedepan adalah, perlunya memahami pola akulturasi mahasiswa yang berasal dari luar daerah ketika berada di perguruan tinggi. Hal tersebut menjadi penting untuk dibicarakan mengingat jika semua orang mengalami kendala yang hampir serupa, maka kendala-kendala tersebut dapat disarikan dan kemudian 
disampaikan kepada calon mahasiswa dari luar kota. Sehingga hambatan-hambatan komunikasi kedepannya akan semakin berkurang serta meningkatkan efektifitas komunikasi bagi mahasiswa. 


\section{DAFTAR PUSTAKA}

\section{Buku dan Jurnal}

Anwar, R., \& Cangara, H. (2016). Rintangan Komunikasi Antar Budaya Dalam The Intercultural Communication Barriers of Marriage and Divorce Between Java and Papua Ethnics in The City of Jayapura (Conflict Management Strategy in Husband and Wife Interpersonal Relationship). Jurnal Komunikasi KAREBA, 5(2), 273-285. https://doi.org/10.31947/kjik.v5I2.1906

Aw, S. (2015). Implementasi Teori Komunikasi Sosial Budaya Dalam Pembangunan Integrasi Bangsa. Informasi, 45(1), 65. https://doi.org/10.21831/informasi.v45i1.7771

Barker, G. G., \& Cornwell, T. L. (2019). Acculturation, Communication, and Family Relationships: Challenges and Opportunities. Western Journal of Communication, 83(0), 1-23. https://doi.org/10.1080/10570314.2019.1620961

Chaney, L. H., \& Martin, J. S. (2014). Intercultural Business Communication (Internatio). New Jersey: Pearson.

Data, S. S. (2014). Perubahan Pola Komunikasi Masyarakat Komunitas Suku Sasak Dusun Sade (Suatu Studi Etnografi di Desa Wisata Komunitas Suku Sasak Dusun Sade Lombok Tengah). Universitas Gadjah Mada.

DeVito, J. A. (2014). Human Communication: The Basic Course (2014th ed.; E. Harlow, Ed.). Pearson.

Heryadi, H., \& Silvana, H. (2013). Komunikasi Antarbudaya Dalam Masyarakat Multikultur. Jurnal Kajian Komunikasi, 1(1), 95-108. https://doi.org/10.24198/jkk.vol1n1.9

Jandt, F. E. (2017). Conflict \& Communication. California: Thousand Oaks: SAGE Publications.

Khatimah, K., Saleh, R., \& Comn, M. (2018). Pola Komunikasi Antarbudaya Dalam Keberagaman Suku Di Daerah Perbatasan Provinsi Aceh (Studi Pada Suku Singkil Dengan Suku Pendatang Di Kecamatan Simpang Kiri Kota Subulussalam. Jurnal Ilmiah Mahasiswa FISIP Unsyiah, 3(2), 279-292.

Liliweri, A. (2007). Dasar-dasar Komunikasi antar budaya (cet. 3). Yogyakarta: Pustaka Pelajar.

Muchtar, K., Koswara, I., \& Setiaman, A. (2019). Komunikasi Antar Budaya Dalam Perspektif Antropologi. Jurnal Manajemen Komunikasi, 1(1), 113-124. https://doi.org/10.24198/jmk.v1i1.10064 
Neuliep, J. W., \& Johnson, M. (2016). A cross-cultural comparison of Ecuadorian and United States face, facework, and conflict styles during interpersonal conflict: An application of face-negotiation theory. Journal of International and Intercultural Communication, 9(1), 1-19. https://doi.org/10.1080/17513057.2016.1120844

Sukmono, F. G., \& Junaedi, F. (2014). Komunikasi Multikultur: Melihat Multikulturalisme dalam Genggaman Media. Yogyakarta: Buku Litera.

Universitas Gadjah Mada: Tentang UGM. (n.d.). Retrieved September 26, 2019, from https://ugm.ac.id/id/tentang

Windaswara, V. (2017). Komunikasi Akulturasi Antarbudaya (Studi Kasus pada Komunikasi Antarbudaya di dalam Akulturasi Siswi SMA Stella Duce 2 Yogyakarta. Universitas Gadjah Mada.

Yin, R. K. (2008). Studi Kasus : Desain dan Metode (1st ed.). Jakarta: Rajagrafindo Persada. 